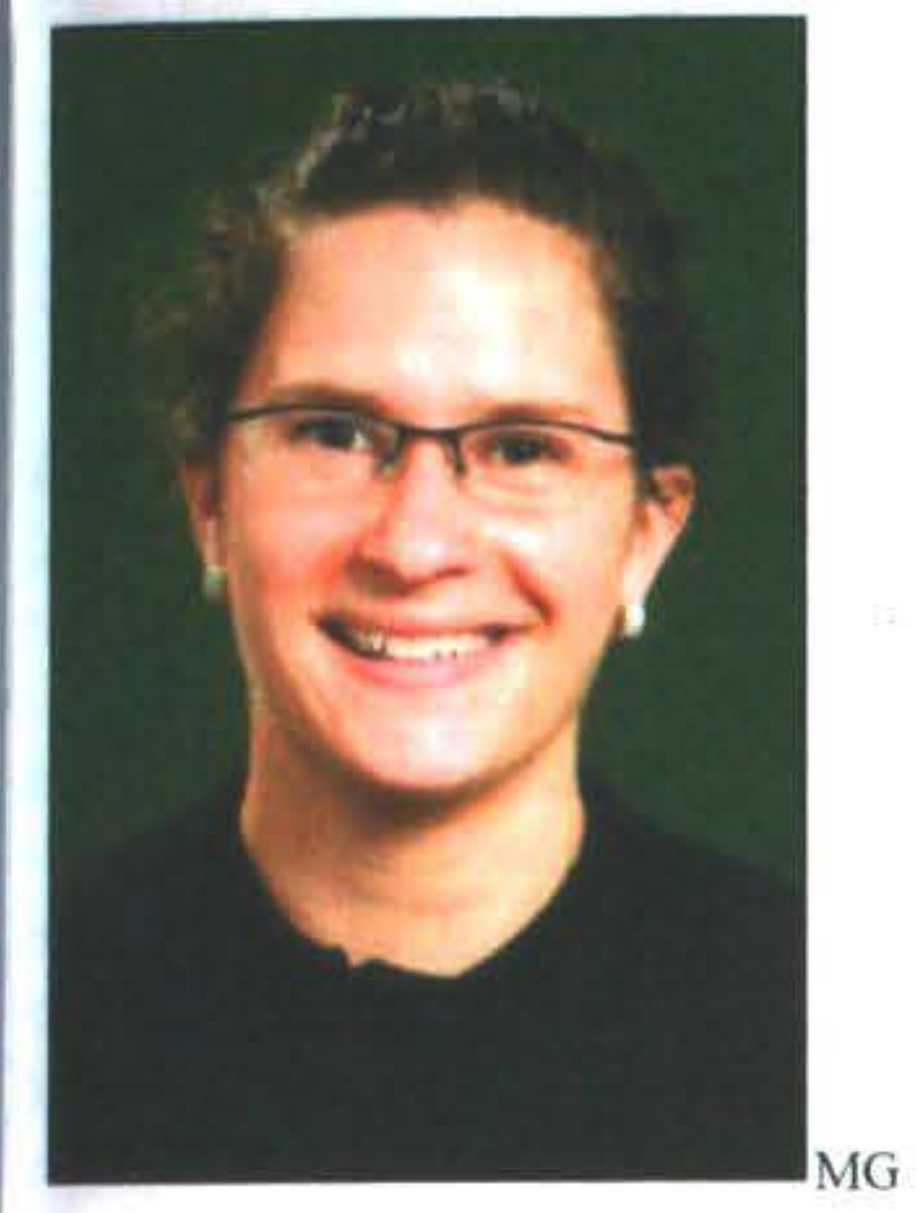

\title{
OCCUPATIONAL NET REPLACEMENT DEMAND IN NEW ZEALAND FROM 1991 TO 2006
}

\author{
Maria Guerra and \\ Ram SriRamaratnam
}

Department of Labour

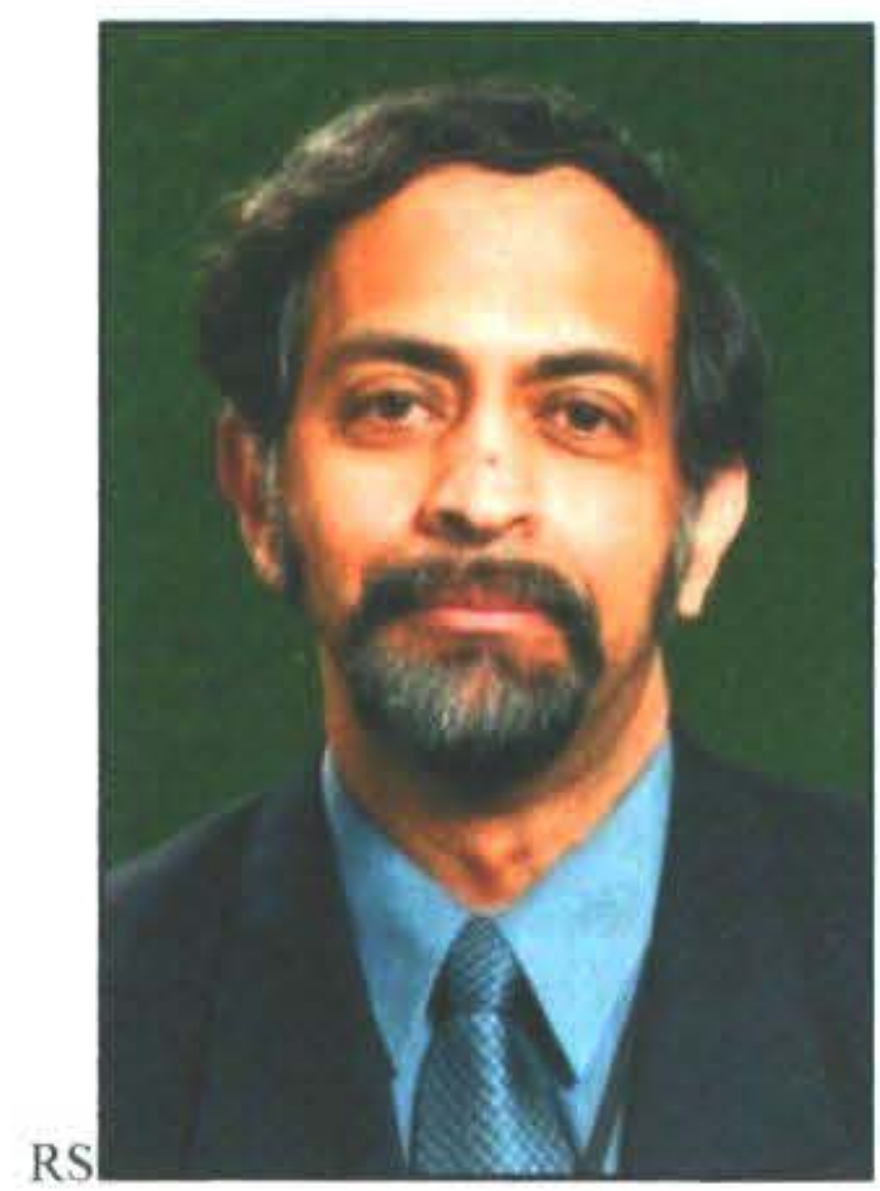

Net replacement demand is defined as the number of job openings that arise from individuals leaving an occupation, net of jobs taken by individuals re-entering an occupation. This gives us a measure of the demand for labour required to replace the current workforce and may be used for resource allocation planning for education and training. This may also be used as an additional diagnostic measure for occupations experiencing recruitment and retention difficulties.

The average net replacement rate estimated across all occupations in New Zealand was in the order of 1.4\% for 3-digit and $1.7 \%$ for 5-digit occupations during 2001-06. The 5-digit rates varied considerably between 0.1 (e.g. microbiologists) and 10 (e.g. checkout operators). Average net replacement demand rates for occupations in New Zealand when compared with those derived in the U.S (2.4\%), Australia (2.0\%) and the Netherlands (3.8\%) suggest somewhat lower domestic rates. Variations in estimates between countries could be explained by differences in the level of occupational mobility as well as the age and gender structure of the workforce. Social and economic policies and differences in each country's retirement schemes and social assistance policies also give rise to differing net replacement demand rates.

\section{Introduction to Net Replacement Demand}

While there are various models that focus on the study and estimation of replacement demand, most definitions of replacement demand are centred on the idea that replacement demand measures the number of job openings that arise for individuals to replace workers leaving an occupation. This could be due to retirement, emigration, moving jobs or temporarily leaving the workforce.

Net replacement demand is often overlooked as an important source of information and can play a significant role in identifying possible job openings for job seekers. Net replacement demand rates may even have equal or greater impacts than job growth, as it can give a more accurate picture of the true number of job openings in an occupation (Shah \& Burke, p. 648, 2001).

Net replacement demand has various uses. It can be valuable in providing information to agencies developing policies around resource allocation for training and education. Additionally, net replacement demand can provide insightful information about recruitment and retention difficulties for particular occupations. For example, occupations that experience outflows in all age cohorts, such as food processing machine operators, may indicate certain problems or issues in their particular industries.

Furthermore, forecasting net replacement demand information together with wage and job growth information can prove very valuable for people deciding on future career paths. This information may further help align supply and demand of workers and also increases the transparency of labour market information. An excellent example of this transparency is a document by Patton (2006). In this document, Patton produced an occupational forecast report for occupations in Alaska outlining net replacement demand (job openings) together with job prospects. The author outlines likely training and education needed to do the occupation, whether the occupation is declining or not and the average earnings expected. This is a step closer to achieving labour market information transparency and availability for all parties.

\section{Overseas studies}

A number of countries study and publish net replacement demand statistics and replacement demand forecasts. These include Australia where the Federal Government publishes total replacement demand for 81 occupational groups (Shah, 1998); the Netherlands through the ROA (Researchcentrum voor Onderwwijs en Arbeidsmarkt Research Centre for Education and the Labour Market); the U.S through the Bureau of Labor Statistics (BLS) and Canada through the Canadian Occupational Projection System (COPS).

\section{Definition of replacement demand in this study}

There are various definitions of replacement demand covered by each of the models mentioned above and these are discussed further in the following section. This paper defines net replacement demand as the number of job 
openings that arise from individuals leaving an occupation net of jobs taken by individuals re-entering an occupation (Shah and Burke, p. 649, 2001). Net replacement demand is the most relevant for advice on education and training needs (Shah and Burke, p. 649, 2001) and therefore is the focus of this paper.

\section{Objective of this paper}

This study closely follows the methodology used in the paper by Shah and Burke (2001) and estimates historical net replacements rates for 96 occupations at the 3-digit NZSCO level in New Zealand between 1991 and 2006 and 5-digit occupations for 2001-2006.

This study does not intend to provide a full comprehensive analysis of each occupation, but gives a reader a taste for what can be done with this type of information. New Zealand estimates are compared with those from Australia, the US and the Netherlands. Forecasts of net replacement demand rates for these occupations are not addressed in this paper and will be the subject of a forthcoming paper.

\section{Concepts of Replacement Demand}

This section defines the concepts of total replacement demand, replacement demand for those outside employment and net replacement demand, as covered in Shah and Burke's study in 2001.

Diagram 1 provides a visual representation of the typical labour mobility in the labour market. It demonstrates the gross inflows and outflows in a particular occupation. Inflows into an occupation can be attributed to individuals leaving education and moving into the labourforce (new entrants), or maybe due to changing jobs (reentrants) or immigration and so forth.

Death, retirement, emigration, changing jobs and the transition out of the workforce or moving out of employment are the primary reasons for outflows from an occupation. Shah and Burke (p. 650, 2001) separates inflows into new entrants and re-entrants, defining new entrants as individuals entering an occupation for the first time and re-entrants as being individuals re-entering an occupation after leaving it temporarily or due to termination. Diagram 1 shows the inflows and outflows of people into an occupation as well as people who remain in an occupation (A).

\section{Total Replacement Demand}

Total replacement demand can be defined as the overall number of job openings resulting from individuals leaving an occupation for any reason, including changing occupations (Shah and Burke, p. 650, 2001). If an occupation is expanding, this is equal to the sum of outflows B, C and D (as shown in Diagram 1). If an occupation is declining, total replacement demand is equal to B, C, and D minus the decline in occupation. The US Bureau of Labor Statistics produces estimates of total replacement demand for approximately 500 U.S occupations (BLS, 1998).

\section{Replacement Demand for those outside employment}

This concept is primarily covered in the Canadian Occupational Projections System (COPS) model and defines the replacement demand for those outside employment "this results from netting out inflows from other occupations (inflows E and F), from total replacement demand". The COPS model excludes fulltime students from all calculations. This is because Bothby et al (1995), claim that students who are about to enter the labour market are a source of labour supply but are often already in the labour market and therefore should not be counted when estimating replacement demand (Shah and Burke, p. 651, 2001).

\section{Net Replacement Demand}

Net replacement demand attempts to measure job openings for new entrants to an occupation. In Diagram 1 , net replacement demand is defined as the sum of outflows B, C and D minus the re-entrants F, H and $\mathrm{J}$ into an occupation. Net replacement demand figures are estimated in the Shah and Burke (2001) paper, for approximately 81 occupational groups as well as in the ROA model where 80 occupational classes are covered.

It is important to recognise that if there is a high mobility within an occupation, then this will result in a lower net replacement demand rate. Net replacement demand attempts to capture the measure of turnover coupled with those changing occupation and/or moving in and out of the labour force in order to determine the demand for skills and/or training to maintain the current workforce.

\section{Caveats of the net replacement demand measure}

It must be noted that net replacement demand is not only a measure of outflows due to workers changing jobs, exiting the labour force and migration but also in some sense an implicit measure of retirement (Access Economics, p. 48, 2005). Furthermore, it does not tell us anything about inflows into an occupation. In other words, it would be useful to identify the source and size of inflows into an occupation to get a better understanding of the current supply and demand of skills.

Additionally, Access Economics (p. 47, 2005) explains that this methodology does not enables us to know the skill level of re-entrants and therefore, this net replacement demand measure is most likely overestimating the demand for training for these individuals. Furthermore, we do not know anything about whether the people in the first year are the same people that stay on in the occupation in the second period and therefore we do not know the level or demand for training that these people need. 


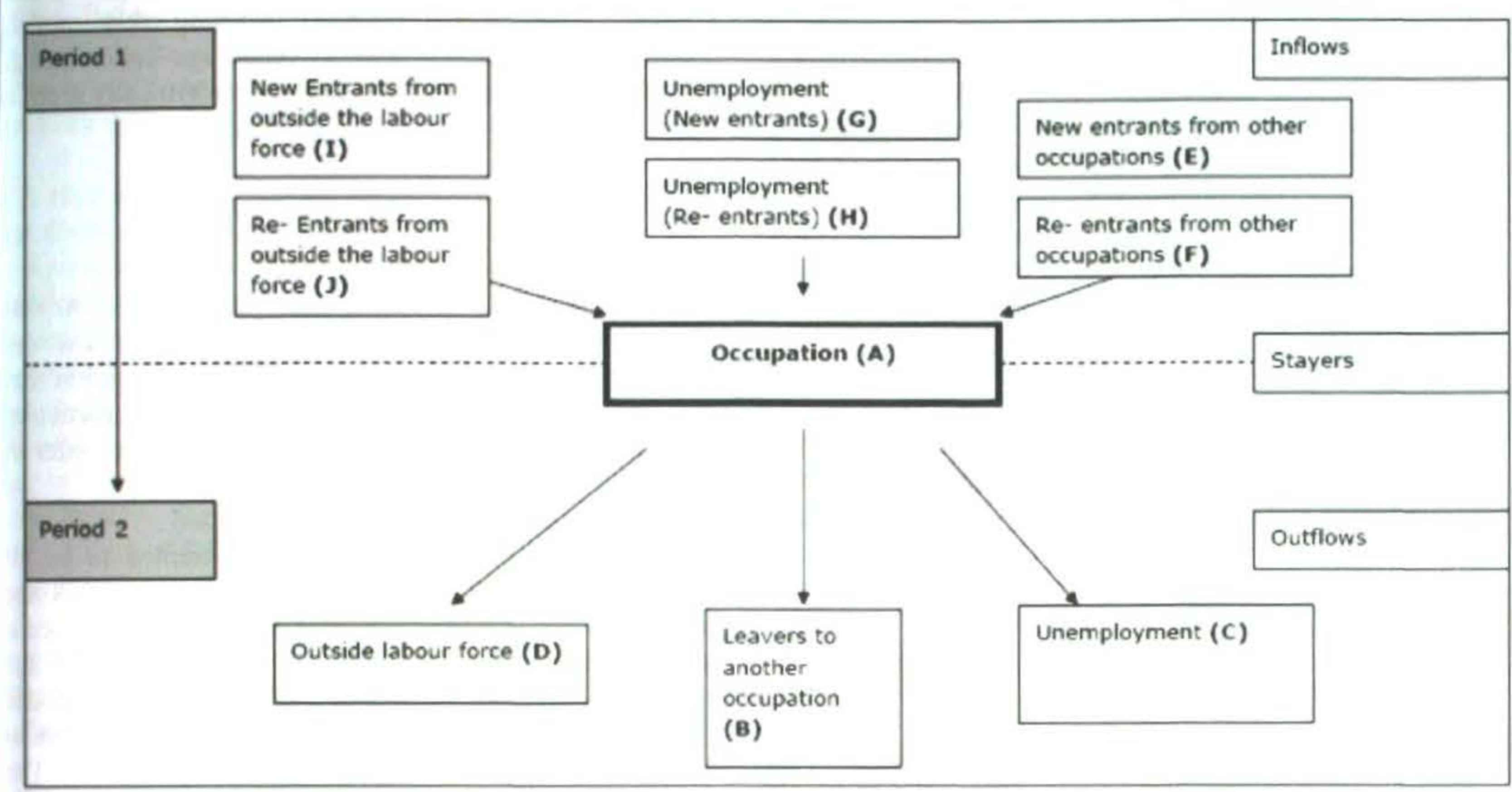

Source: This diagram is an adaptation of the Table 1 in Shah and Burke (2001) and Figure 1 in Willems and de Grip (1993)

\section{Methodology of Net Replacement Demand: Application to New Zealand}

This study focuses on estimating historical net replacement demand rates in New Zealand for the period 1991 through to 2006 for 3-digit occupations and 5-digit net replacement demand rates.

\section{Data Used}

Data used in this study was extracted from the 1991, 1996, 2001 and 2006 New Zealand Censuses of Population and Dwellings ${ }^{1}$. The New Zealand Population and Dwellings Census is conducted every 5 years and collects information on several demographic and socioeconomic features. This differs to the Australian Bureau of Statistics' labour mobility data; a supplement to the Labour Force Survey dataset used in the study by Shah and Burke (2001). Data from the New Zealand Population and Dwellings Census (Census) was considered more accurate, complete and, by the nature of being a Census, offers greater levels of disaggregation and confidence than other sources of similar data in New Zealand, such as the quarterly Household Labour Force Survey (HLFS) where sample sizes for certain occupations by age-cohorts could be limiting.

In order to measure the outflows between Census years for an occupation, occupational employment at the 3-digit level New Zealand Standard Classification Occupation (NZSCO) was used. The study population consisted of the working-age population (15 year and over) divided into 5 year age cohorts.

\section{The disadvantage of using Census data}

Ideally, data from the Census would provide details of the sources of outflows in order to calculate net replacement demand rates. However, due to the nature of the data, it is not possible to distinguish between new entrants and re-entrants to an occupation. Additionally, it is also not possible to determine the type of mobility for occupations individuals have experienced during separate years in between Census years and therefore the sources of outflows due to an employee changing jobs, death, retirement or emigration cannot be differentiated.

Nevertheless, it is possible to estimate net replacement demand rates by using the cohort-component method described in the following section. 3-Digit rates are calculated because it directly avoids the comparability problem using 5-digit rates due to a change in occupational coding system in 1996. For this reason, 5digit net replacement demand rates are only calculated for the 2001-2006 period.

Unlike, the Shah and Burke (2001) paper, the gender variable is not included for reasons of simplicity.

\section{Cohort-component method}

The cohort-component method outlined by Eck (1991) and Willems and de Grip (1993) can be utilised to approximate net replacement rates. This is because it allows estimation of flow rates in and out of an occupation by taking into account net changes in cohort sizes over a given period (Shah and Burke, p. 651, 2001).

The authors outline how this method has been used for a variety of different purposes including estimating survival 
ratios (ABS, 1992) and progression rates through courses in higher education (Shah and Burke, 1999).

The cohort-component method uses data at two different points in time, to establish the inflows and the outflows for an occupation by age-cohorts. Annual data is typically used, however due to the lack of availability of this type of data for New Zealand, five yearly Census data was used. As a result, a particular occupation of cohort age $a$ in a particular Census is compared to the same cohort in the next Census five years later.

\section{Definition of net outflows}

Shah and Burke (p. 652, 2001) describe the net flow from an occupation as being the change in size of cohort over a certain period and given by:

$$
F_{a t}=E_{a+1 t+1}-E_{a t}
$$

Where $\mathrm{F}_{\mathrm{at}}$ is the net flow from age cohort $a$ at time $t$

The authors go on to outline that if the size of the cohort decreased $\left(\mathrm{F}_{\mathrm{at}}<0\right)$, then there has been an outflow $\left(-\mathrm{F}_{\mathrm{at}}\right)$, otherwise the net outflow is equal to zero. This is true if the employment in an occupation is expanding, however if employment is decreasing then the net outflow is equal to sum of outflows minus the size of the contraction.
This method approximates net replacement demand as it estimates "the number of leavers from an occupation less (mostly) re-entrants" (p. 652). Using this model, outflows are generally seen in older age cohorts (e.g. through retirement) and new entrants are typically seen in the younger ones (e.g. from education).

\section{Example of net replacement demand calculations}

Table 1 presents a similar hypothetical example to that given in Shah and Burke (2001), showing how net replacement demand is calculated for an occupation that is increasing in size. Employment numbers in a particular age cohort are compared in 2001 and five years later in 2006.

For simplicity the retirement age is assumed to be 40 years and therefore there are $100 \%$ outflows in this age cohort. As can be seen from table 1, most outflows occur in the older age cohorts, in this case, the 25-39 age cohorts. Therefore, all workers in the older age groups need to be replaced. Conversely, increases in inflows in the younger age cohorts are due to new entrants. The sum of outflows (200) from this occupation approximates the number of number of job openings available for new entrants or shows the net replacement demand in this occupation.

Table 1: Hypothetical example of net replacement demand for an occupation where employment is increasing ${ }^{a}$

\begin{tabular}{|c|c|c|c|c|c|}
\hline $\begin{array}{l}\text { Age cohort } \\
\text { 2001 }\end{array}$ & $\begin{array}{l}\text { Employment } 2001 \\
\text { (Parind }\end{array}$ & Age cohort 2006 & $\begin{array}{l}\text { Employment } 2006 \\
\text { (Perind it) }\end{array}$ & $\begin{array}{c}\text { Employment Change 2001- } \\
\text { 2006 }\end{array}$ & $\begin{array}{l}\text { Net Flow } \\
2001-2005\end{array}$ \\
\hline & & $15-19$ years & 90 & 90 & $0^{b}$ \\
\hline $15-19$ years & 100 & $20-24$ years & 180 & 80 & $0^{b}$ \\
\hline $20-24$ years & 200 & $25-29$ years & 250 & 50 & $0^{b}$ \\
\hline $25-29$ years & 240 & $30-34$ years & 200 & -40 & $40^{c}$ \\
\hline $30-34$ years & 180 & $35-39$ years & 120 & -60 & $60^{c}$ \\
\hline $35-39$ years & 100 & 40 years and over & 0 & -100 & $100^{c}$ \\
\hline Total & 820 & & 840 & 20 & $200^{d}$ \\
\hline \multicolumn{6}{|c|}{ If an occupation is decreasing then the change in employment (loss) is subtracted from the total net outflows. } \\
\hline \multicolumn{6}{|c|}{ The net outflow is equal to zero, as no employees need to be replaced. } \\
\hline \multicolumn{6}{|c|}{ Net Replacement demand rate $=\frac{200}{820} \div 5=4.9^{\circ}$} \\
\hline
\end{tabular}

\section{Assumption about retirement age in the model}

In this study the retirement age is assumed to be 70 and over. An extra cohort was added into the data that included the $70+$ category and all employment in this category was assumed to equal zero and therefore $100 \%$ of outflows are from this cohort. This is necessary as New Zealand does not have a compulsory retirement age: however most people retire by the age of 70 . While some people remain in employment over the age of 70 , they make up a small proportion of the overall workforce. The assumption that people over the age of 70 are not in work is used by Shah and Burke (2001) as well as in the ROA model.

\section{Historical Net Replacement Demand Estimates for New Zealand}

This section briefly discusses the results for a subset of 3digit occupations in this study. It is not intended to provide a full analysis for all occupations. The objective is to give the reader an idea of how this data could be used to investigate what is going on in an occupation with respect to outflows. 
There are a variety of observable factors that affect net replacement demand rates within a certain occupation. These factors include the age distribution within an occupation, income, skill level of an occupation and whether an occupation is experiencing recruitment and retention difficulties.

The results showed that occupations that had a younger age distribution, tended to be associated with higher net replacement demand rates. This was particularly true for cashiers, tellers and related clerks at the 3-digit occupational group level, where a large proportion of individuals fell into the 15-19 age group and the average age in 2006 was 33 years, well below 41 years for all occupations (figure 1). The average net replacement demand rate for this group of $4.8 \%$ percent was considerably higher than the average rate for all occupations of $1.4 \%$ between 2001 and 2006 . There are several reasons driving this higher than average result. First, this is a low-skilled occupation and therefore exhibits low average tenure and secondly, people do not return to these types of jobs after a certain age (C. Shah, personal communication, April 10,2008).

However, a younger average age does not always yield a high net replacement demand rate, as seen with the case for computing professionals (figure 2). The results showed that this occupation had the lowest net replacement demand rate, between 2001 and 2006, of $0.2 \%$, while the average age for this occupation was relatively young ( 37 years). And so, it seems that other factors were driving the very low result. According to the 2006 Census the average annual income was $\$ 59,000$, well above the average income for all occupations of $\$ 38,900$ and may help explain larger inflows compared to outflows within this occupation (Shah \& Burke, p. 657, 2001). The low net replacement demand result is somehow puzzling given that this occupation is usually associated with a high turnover. However, examining more closely, high mobility within this occupation would also result in low net replacement demand rates. Additionally, this lower net replacement demand rate could be due to the occupation being relatively new when compared with other professional occupations (C. Shah, personal communication, April 10, 2008).

3-Digit occupations with net replacement demand rates around the average for all occupations of 1.4 percent, such as health associate professionals $(1.5 \%)$ shown in figure 3 , exhibited net outflows in older age groups and therefore showed a retirement pattern typically seen in the average occupation.

Occupations experiencing recruitment and retention difficulties may explain a higher than average net replacement demand rates. An occupation is said to experience recruitment and retention difficulties when there is a sufficient supply of individuals with the required skills in the potential labour market but insufficient numbers are willing to take up employment at current levels of remuneration and conditions of employment. Retention problems are often a major contributor to this condition. The results showed that semi-skilled or elementary occupations such as food and related products processing machine operators experienced high outflows in nearly all age groups. Further research is needed to confirm this view, however high outflows particularly across all age groups could be a symptom of this type of problem.

Table 2: Summary of Results

\begin{tabular}{|c|c|c|c|c|c|}
\hline NZSCO & Occupation & Employment 2006 & Average income & Average Aze & $\begin{array}{l}\text { Annual Average net } \\
\text { replacement demand rate }\end{array}$ \\
\hline 421 & $\begin{array}{l}\text { Cashiers, Tellers and } \\
\text { Related Clerks }\end{array}$ & 32,600 & $\$ 24,500$ & 33 & $4.80 \%$ \\
\hline 42112 & Checkout Operators & 12,921 & $\$ 10,300$ & 26 & $10.10 \%$ \\
\hline 42111 & Cashiers & 3,882 & $\$ 16,300$ & 33 & $1.30 \%$ \\
\hline 42151 & Bill and Debt Collectors & 11,236 & $\$ 36,100$ & 38 & $1.00 \%$ \\
\hline 322 & $\begin{array}{l}\text { Health Associate } \\
\text { Professionals }\end{array}$ & 11,208 & $\$ 36,700$ & 41 & $1.50 \%$ \\
\hline 32241 & Veterinary Assistant & 1,263 & $\$ 26,400$ & 34 & $4.00 \%$ \\
\hline 32252 & $\begin{array}{l}\text { Retail Dis pensary } \\
\text { Assistant }\end{array}$ & 87 & $\$ 38,500$ & 38 & $0.10 \%$ \\
\hline 223 & $\begin{array}{l}\text { Nursing and Mid wifery } \\
\text { Professionals }\end{array}$ & 35,148 & $\$ 41,000$ & 45 & $0.90 \%$ \\
\hline 22311 & Plunket Nurse & 495 & $\$ 34,400$ & 46 & $3.10 \%$ \\
\hline 22314 & Principal Nurse & 1,455 & $\$ 52,800$ & 48 & $0.30 \%$ \\
\hline 213 & $\begin{array}{l}\text { Computing } \\
\text { Professionals }\end{array}$ & 27,858 & $\$ 59,200$ & 37 & $0.20 \%$ \\
\hline 21311 & Systems Engineer & 7,656 & $\$ 67,00$ & 38 & $0.90 \%$ \\
\hline 21312 & $\begin{array}{l}\text { Computer Applications } \\
\text { Engineer }\end{array}$ & 14,193 & $\$ 58,300$ & 36 & $0.10 \%$ \\
\hline
\end{tabular}


Figure 1: Age Profile and net outflows of Cashiers, Tellers and Related Clerks

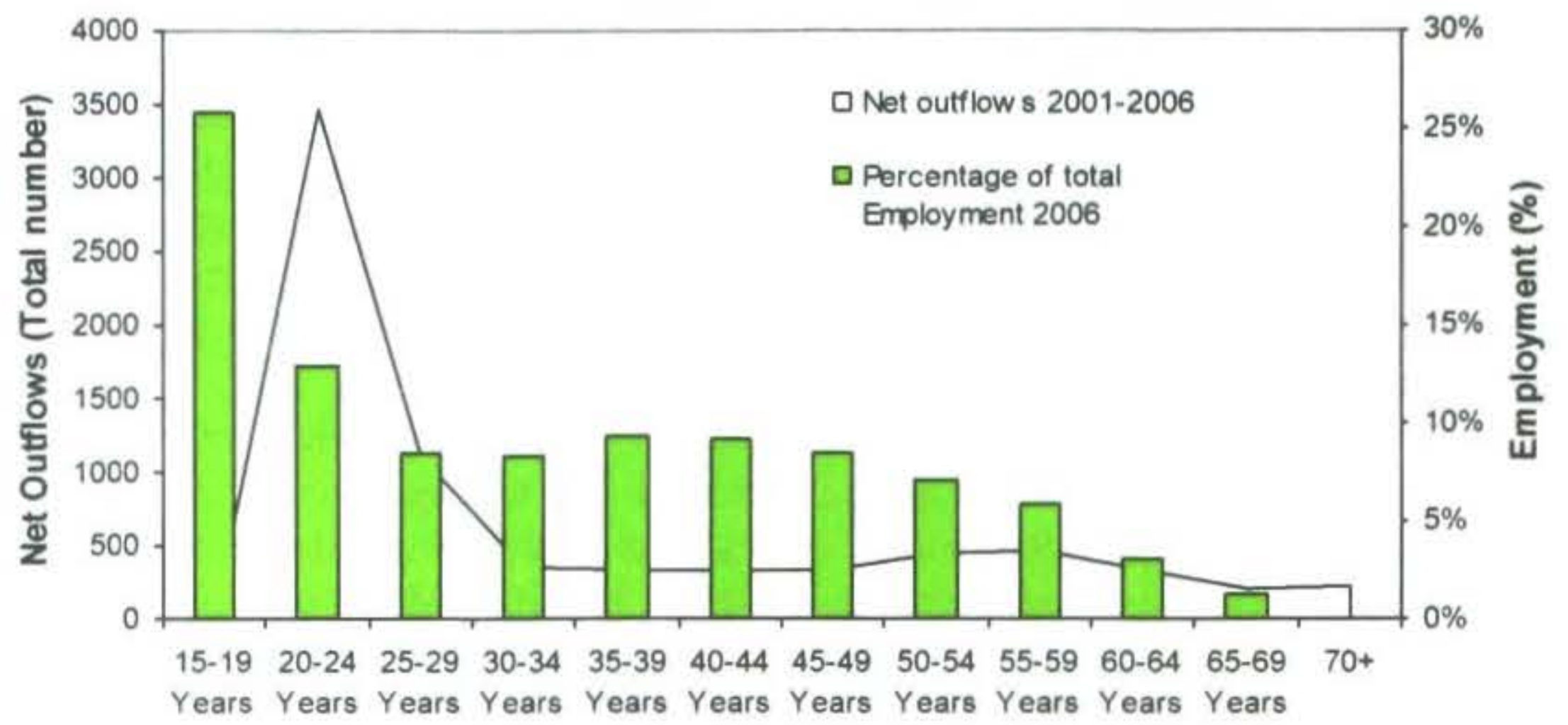

Figure 2: Age Profile and net outflows of Computing Professionals

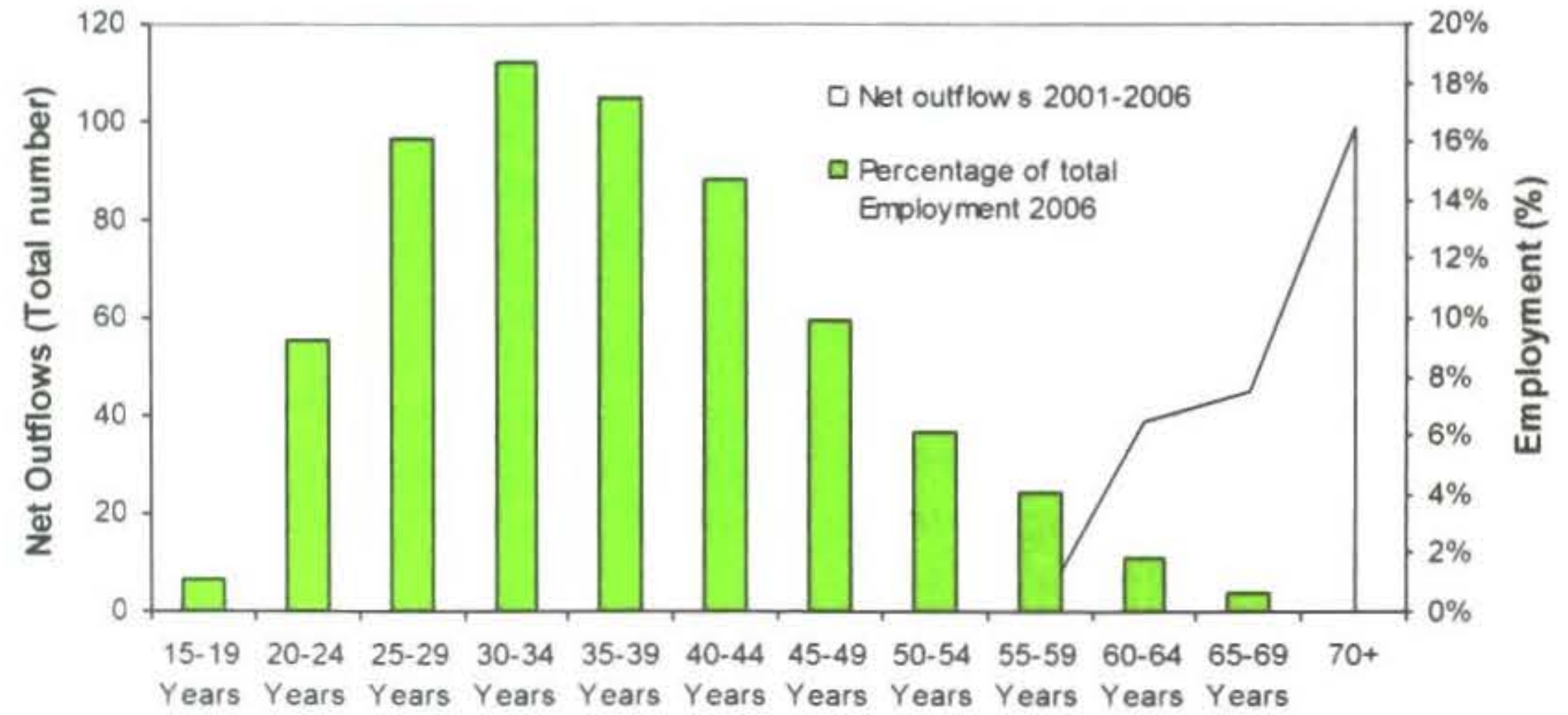

Figure 3: Age Profile and net outflows of Health Associate Professionals

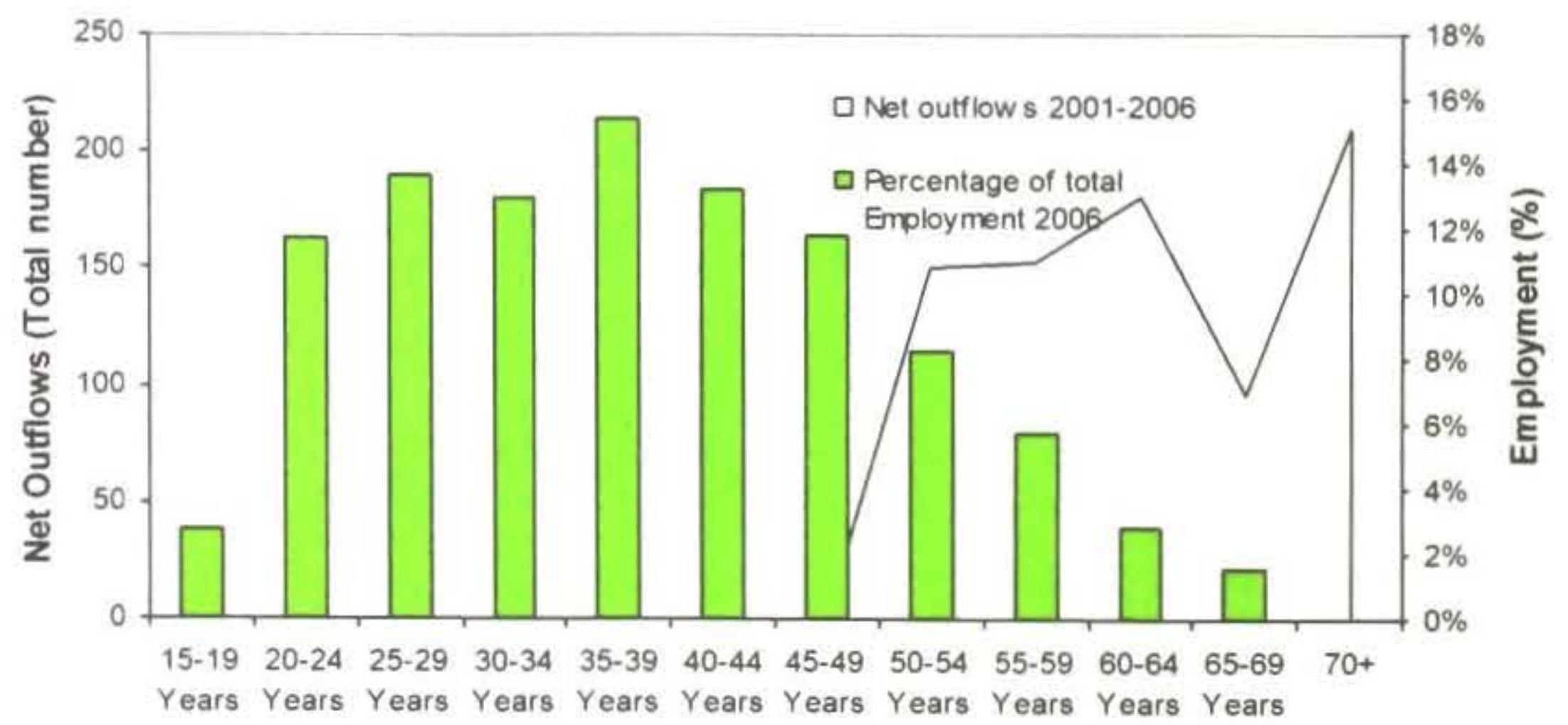




\section{International comparison of net replacement estimates}

This sections gives an overview of the net replacement demand rates for the U.S, Australia, The Netherlands and New Zealand and explores possible reasons for differing rates between countries.

The average net replacement rates for the U.S, Australia, The Netherlands and New Zealand are 2.4\%,2\%,3.8\% and $1.4 \%{ }^{2}$ respectively. U.S net replacement rates were taken from the BLS (2006) and related to the period 2004-2014. Rates for Australia (1999-2003) and the Netherlands were obtained from the Shah and Burke (2001) paper. Due to the unavailability of comparable estimates and data, rates cannot be compared for corresponding periods.

U.S net replacement demand rates across all occupations range from $1.0 \%$ to $6.2 \%$. In Australia, rates ranged from around $0.5 \%$ to over $6 \%$ for the $1999-2003$ period, while in The Netherlands the minimum was $2 \%$ (Shah and Burke, 2001, p. 658). Rates in New Zealand varied from $0.2 \%$ to just over $5 \%$ between 2001 and 2006 .

\section{Example of possible reasons for differences in estimates internationally}

Differences in international net replacement demand rates could be due to a variety of reasons. For example, differences in the age and gender structure of the workforce of the respective countries along with their social and economic policies and differences in assumptions made in each country's model (Shah and Burke, 2001, p. 658). More specifically, differences in net replacement demand might be explained by the same financial drivers that influence workers to move in and out of the labour force. For example, Nickell and Nunziata (2002) state that changes in the unemployment benefit system directly influences the readiness of the unemployed to fill vacancies (p.4). Additionally, incentives created by different retirement schemes and changes to social assistance over recent years in the U.S, Australia and New Zealand may also have an influence on net replacement rates.

\section{Retirement schemes and their influence on net replacement rates}

Differences in retirement schemes are an interesting feature to examine more closely that could explain changes in net replacement rates across different countries (Shah and Burke, 2001).

The Netherlands have one of the lowest participation rates in the OECD in the 55-64 age cohort (Euwals et al, 2006). Higher net replacement rates in the Netherlands could be explained by the generous retirement schemes, in the past. However, Euwals et al (2006), argue that retirement behaviour has changed in the Netherlands, since the policy reform towards less generous and actuarially fair capital funded schemes took place. Their study claims that this policy reform has transitionally induced workers to post pone early retirement.
This change in behaviour may have some effect when estimating future net replacement estimates for this type of situation. Therefore, it is imperative that policy changes and their affect on the labour market are recognised when attempting to forecast.

\section{New Zealand Superannuation}

On the other hand, New Zealand has one of the highest participation rates of older workers in the OECD. This trend, Hurnard (p.1, 2005) argues, has been primarily due to the change in age of eligibility for the New Zealand Superannuation (NZS) from 60 to 65 .

The author goes on to state that the New Zealand incentives that have encouraged older workers to stay in the labour force, are due to the unique features in the public pension design. These include:

- having no legal impediment for continuing to be employed beyond the New Superannuation eligibility age;

- not having a compulsory retirement age;

- the New Zealand Superannuation is not work or income tested (meaning that a worker eligible for NZS can continue to work with no financial penalty while receiving NZS); and

- the absence of an early eligibility option for the NZS will mean that people will be more likely to stay in the labour force until they are eligible for the NZS (p. 19, 2005).

These incentives, unique to New Zealand, could all explain why New Zealand has overall lower net replacement rates when compared to the U.S, the Netherlands and Australia, because older workers in New Zealand do not have strong incentives to retire early.

\section{Assumption about retirement age}

Assumptions about the retirement age play an important part in determining net replacement rates. Shah and Burke (p. 658, 2001) explain that the lower retirement age (65 years) assumption in the ROA model may also explain why net replacement rates are higher in the Netherlands. Conversely, having a higher retirement age assumption in the New Zealand methodology might also help account for low net replacement rates. Then again, a higher assumed retirement age (70 years) in the New Zealand case may align with the fact that New Zealand has higher than average participation rates in the 55-64 age cohort.

\section{Conclusion}

The main aim of this paper was to estimate historical net replacement demand rates for 96 3-digit NZSCO occupations in New Zealand over the three 5 year Census periods 1991-2006 (shown in Appendix A) and for $5605-$ digit NZSCO occupations between 2001 and $2006^{3}$. 
The results show that between 2001 and 2006 an estimated 26,400 annual job openings at the 3-digit occupational level and 28,200 at the 5-digit occupational level were due to net replacement demand. Furthermore, net replacement demand rates in New Zealand for 3-digit NZSCO occupations ranged from $0.2 \%$ to just over $5 \%$ and zero to $10.1 \%$ for 5 -digit occupations.

When combined with wage information and growth of additional or new jobs created, net replacement demand rates may prove extremely valuable for job seekers as it provides a more accurate picture of the full extent and distribution of jobs openings. Additionally, net replacement rates may be used for assessing the costeffectiveness of policies on training (Shah and Burke, p.659, 2001).

Furthermore, net replacement demand rates may provide an indication of which occupations have and could experience retention and recruitment difficulties which could be further explored by employers and policy makers.

Variations in rates could also be explained by the differing nature and skill levels of occupational groups. For example, higher rates seemed to occur in lower skilled occupations, such as cashiers, tellers and related clerks. While this was primarily due the lower skill level, this could also be due to the transitory nature of these occupations experiencing larger net outflows in younger age groups. High net replacement demand rates for low skill occupations can also be due to low average tenure and because people do not tend to return to such jobs after a certain age.

On the other hand, very low net replacement rates of around $0.2 \%$ were seen in highly skilled professional groups such as computing professionals, at the 3-digit level. Despite having high turnover within individual 5digit computing related occupations, it was assessed that this high mobility may not result in higher net replacement rates for the overall occupational group. These lower rates could also be due to the numerous computer related occupations being relatively new when compared with other professional occupations coupled with a higher than average annual income.

Net replacement demand information informs and provides some insights to the the reader about an aspect of the dynamics of an occupation. In a sense, it is one piece of the puzzle in trying to understand the demand and supply skills for a particular occupation.

Further work needs to be done in not only understanding the inflows into the occupation but where these inflows are coming from. For example, examining the supply of immigrants and graduates into an occupation is needed to understand the current supply of and demand for skills. Therefore, it is imperative that net replacement demand is combined with other data sources such as inflows into an occupation and outflows from an occupation as well as wage rates in order to gain a more complete understanding about an occupation.
As mentioned in Shah and Burke (2001), further research is also needed to investigate the reasons for variations in net replacement demand rates across occupational groups. In the New Zealand case, areas of interest would lie in uncovering the reasons why particular occupational groups are experiencing recruitment and retention difficulties. This would be valuable, as New Zealand is still experiencing a certain level of skill shortage in some occupations. However, the types of shortages and why they may be occurring are yet to be fully understood.

\section{Notes}

1. Data from Statistics New Zealand is randomly rounded to base 3 in order to protect confidentiality.

2. This rate refers to the 3- digit occupation net replacement rate.

3. Net replacement demand rates for 5 digit occupations can be accessed by contacting Maria Guerra Maria.Guerra@dol.govt.nz.

\section{References}

Access Economics (2005). Improved forecasts of Employment Growth and Net Replacement Rates. Report 2005. Australia: Access Economics.

Berman J. and Pfleeger, J. (1997). Which industries are sensitive to business cycles? Monthly Labor Review, February 1997, 19-25.

BLS (Bureau of Labour Statistics, 1998). Occupational Projections and Training Data, Bulletin 2501, U.S Department of Labor, Washington DC.

BLS (Bureau of Labour Statistics, 2006). Occupational Projections and Training Data, Bulletin 2501, U.S Department of Labor, Washington DC.

Bothby, D., Roth, W. and Roy, R. (1995). The Canadian occupational system: a methodological enhancement. Research paper R-92-2, Human Resources Development, Canada, Hull, Quebec.

Eck, A. (1991). Improved estimates of future occupational replacement needs. Monthly Labor Review, November, 95-102.

Euwals, R., van Vuuren, D. and Wolthoff, R. (2006). Early Retirement Behaviour in the Netherlands: Evidence from a Policy Reform. Discussion Paper No. 1992, March 2006: Institute for the study of Labor, Bonn, Germany.

Nickell, S. and Nunziata, L. (2002). Unemployment in the OECD since the 1960 s. what do we know?: Unemployment Conference, 27-28 May. 
London, School of Economics, United Kingdom: Bank of England.

Parnes, H. (1962). Forecasting Educational Needs for Economic and Social Development (Organisation for Economic Co-Operation and Development, Paris).

Patton, M. (2006). The 2004-2014 Occupational Forecast. Insight into Alaska's future job market, November 2006. Alaska: Alaska Department of Labor and Workforce, Research and Analysis Section.

Pool, I., Baxadine,S., Cochrane,W. and Lindop, J. (2005). New Zealand Regions, 19862001:Industries and Occupations. Discussion papers No. 59 December 2005, Population Studies Centre, University of Waikato, Hamilton, New Zealand.

Shah, C. (1998). Forecasting occupational replacement demand. Report to the Department of Employment, Workforce Relations and Small Business, Canberra.

Shah, C. \& Burke (1999). An undergraduate student flow model: Australian higher education. Higher Education 27, 359-375.

Shah, C. \& Burke, G. (2001). Occupational replacement demand in Australia. International Journal of Manpower, 22(7), 648-663.

Willems, E. (1996). Manpower and Modelling Replacement Demand: an Overview. $R O A-W$ 1996/4E. Netherlands, Maastricht: Research of Centre for Education and the Labour Market.

Willems, E. and de Grip, A. (1993). Forecasting replacement demand by occupation and education. International Journal of Forecasting, 9, 173-85.

\section{Author}

Maria Guerra

Department of Labour

PO Box 3705

Wellington

Maria.Guerra@dol.govt.nz

Ram SriRamaratnam

Principal Analyst of Modelling in Work and Directions

Department of Labour.

P.O. Box 3705

Wellington

Ram.SriRamaratnam@dol.govt.nz 

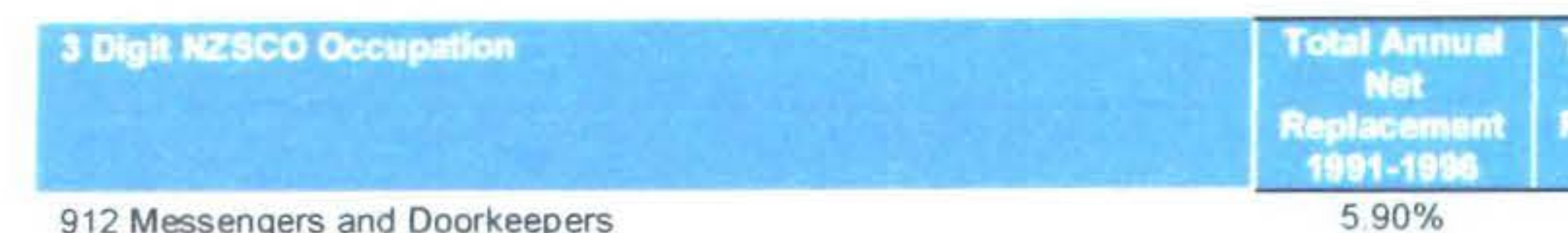

421 Cashiers, Tellers and Related Clerks

523 Fashion and Other Models

111 Legislators

732 Glass Cutters and Related Workers

512 Housekeeping and Restaurant Services Workers

744 Leather Goods Makers

211 Physicists, Chemists and Related Professionals

521 Salespersons and Demonstrators

741 Food and Related Products Processing Trades Workers

721 Metal Moulders, Sheet-Metal and Related Workers

731 Precision Instrument Makers and Related Workers

834 Ships' Deck Crews and Related Workers

422 Client Information Clerks

612 Market Oriented Animal Producers

823 Rubber and Plastics Products Machine Operators

827 Food and Related Products Processing Machine Operators

813 Glass and Ceramics Kiln and Related Plant Operators

$\begin{array}{ll}5.90 \% & 7.20 \% \\ 3.70 \% & 4.60 \% \\ 3.10 \% & 3.00 \% \\ 2.20 \% & 3.90 \% \\ 2.00 \% & 1.40 \% \\ 2.50 \% & 4.30 \% \\ 1.20 \% & 0.00 \% \\ 120 \% & 1.00 \% \\ 2.10 \% & 4.30 \% \\ 2.70 \% & 2.20 \% \\ 1.90 \% & 1.60 \% \\ 1.70 \% & 1.90 \% \\ 2.60 \% & 1.40 \% \\ 0.90 \% & 2.70 \% \\ 2.00 \% & 1.50 \% \\ 2.70 \% & 2.70 \% \\ 3.20 \% & 0.80 \% \\ 2.10 \% & 1.70 \% \\ & \end{array}$

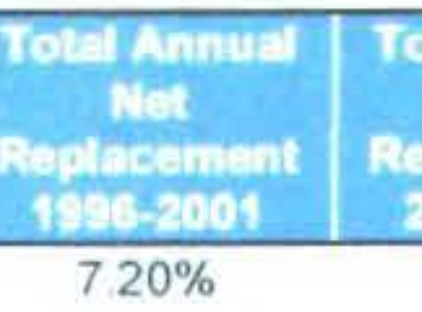

$60 \%$

$3.00 \%$

$390 \%$

$1.40 \%$

(30\%

$100 \%$

$4.30 \%$

$2.20 \%$

$1,60 \%$

$40 \%$

$2.70 \%$

$1.50 \%$

$2.70 \%$

$170 \%$

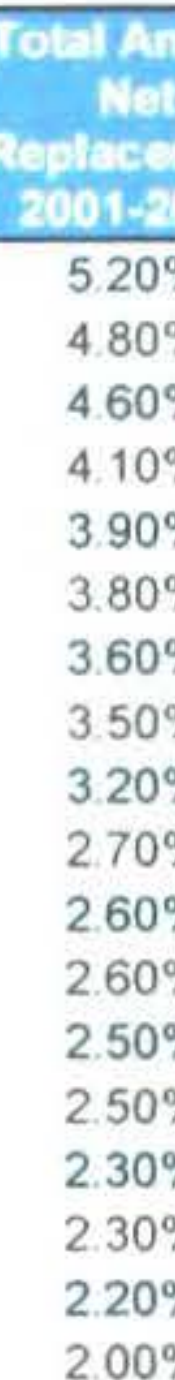

\begin{tabular}{|r|r|}
\hline Tote \\
\hline Enploy \\
$\mathbf{1 9 8}$ \\
\hline 6,807 \\
31,863 \\
78 \\
327 \\
243 \\
44,274 \\
966 \\
1,554 \\
76,020 \\
9,312 \\
15,645 \\
2,325 \\
1,197 \\
21,804 \\
93,636 \\
3,243 \\
24,444 \\
1,725 \\
\hline
\end{tabular}

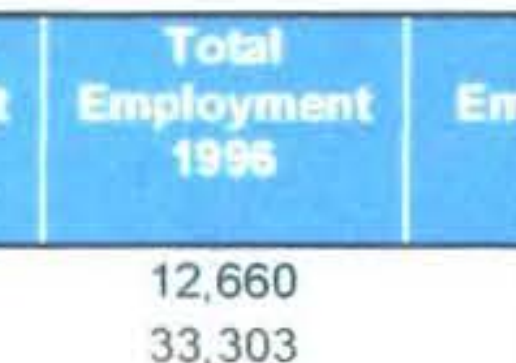

\section{Dight Kresco Occupation}

831 Railway Engine Drivers and Related Workers

312 Computer Equipment Controllers

724 Electrical and Electronic instrument Mechanics and Fitters

232 Secondary Teaching Professionals

822 Chemical Products Machine Operators

911 Building Caretakers and Cleaners

245 Religious Professionals

742 Cabinet Makers and Related Workers

522 Street Vendors

337 Non-Ordained Religious Associate Professionals

829 Assemblers

233 Primary and Early Childhood Teaching Professionals

913 Refuse Collectors and Related Labourers

322 Health Associate Professionals

712 Building Finishers and Related Trades Workers

824 Wood Products Machine Operators

722 Blacksmiths, Toolmakers and Related Workers

815 Chemical Processing Plant Operators

\begin{tabular}{|c|c|c|c|c|c|c|c|}
\hline $\begin{array}{l}\text { Total Annuly } \\
\text { Net } \\
\text { Replacement } \\
\text { 1991-1996 }\end{array}$ & $\begin{array}{l}\text { Total Annual } \\
\text { Net } \\
\text { Replacement } \\
\text { 1996-2001 }\end{array}$ & $\begin{array}{l}\text { Total Annual } \\
\text { Net } \\
\text { Replacement } \\
2001-2008\end{array}$ & $\begin{array}{l}\text { Total } \\
\text { Employment } \\
1991\end{array}$ & $\begin{array}{l}\text { Total } \\
\text { Employment } \\
1996\end{array}$ & $\begin{array}{l}\text { Total } \\
\text { Employment } \\
2001\end{array}$ & $\begin{array}{l}\text { Total } \\
\text { Employment } \\
2006\end{array}$ & $\begin{array}{l}2006 \text { Mean } \\
\text { Income }\end{array}$ \\
\hline $0.20 \%$ & $1.40 \%$ & $1.90 \%$ & 1,137 & 693 & 681 & 750 & 50,000 \\
\hline $2.20 \%$ & $2.30 \%$ & $1.90 \%$ & 9,816 & 8.823 & 9,168 & 7.911 & 50,400 \\
\hline $1.40 \%$ & $1.80 \%$ & $1.90 \%$ & 3,132 & 3,321 & 3,192 & 3,360 & 40,200 \\
\hline $1.90 \%$ & $1.50 \%$ & $1.90 \%$ & 17,145 & 16,602 & 18,528 & 21,180 & 50,600 \\
\hline $3.10 \%$ & $2.90 \%$ & $1.90 \%$ & 1,884 & 1,821 & 1,881 & 1,503 & 28,400 \\
\hline $1.50 \%$ & $2.70 \%$ & $1.80 \%$ & 29,145 & 36,360 & 37,029 & 38,943 & 17,700 \\
\hline $1.70 \%$ & $1.30 \%$ & $1.70 \%$ & 3,306 & 3,093 & 3,492 & 3,756 & 31,400 \\
\hline $0.80 \%$ & $1.80 \%$ & $1.70 \%$ & 4.263 & 5,007 & 4,746 & 4,062 & 32,800 \\
\hline $300 \%$ & $2.40 \%$ & $1.60 \%$ & 1.719 & 1.929 & 1,542 & 990 & 32,500 \\
\hline $2.50 \%$ & $2.20 \%$ & $1.60 \%$ & 606 & 699 & 687 & 840 & 22,300 \\
\hline $1.90 \%$ & $1.60 \%$ & $1.50 \%$ & 11,418 & 9,708 & 9,417 & 8,625 & 35,400 \\
\hline $2.00 \%$ & $1.10 \%$ & $1.50 \%$ & 27,858 & 31,407 & 37.899 & 43,692 & 37,300 \\
\hline $1.50 \%$ & $0.20 \%$ & $1.50 \%$ & 717 & 858 & 1,128 & 1.224 & 27,800 \\
\hline $0.80 \%$ & $0.60 \%$ & $1.50 \%$ & 6.468 & 8,133 & 10,623 & 11,208 & 36,700 \\
\hline $1.40 \%$ & $1.60 \%$ & $1.50 \%$ & 20,721 & 23,016 & 23,346 & 26,223 & 35,200 \\
\hline $0.30 \%$ & $2.10 \%$ & $1.50 \%$ & 1,356 & 2,400 & 2,394 & 2,487 & 35,900 \\
\hline $1.80 \%$ & $0.90 \%$ & $1.40 \%$ & 7,938 & 7,044 & 5,802 & 5,076 & 44,100 \\
\hline $1.70 \%$ & $1.10 \%$ & $1.40 \%$ & 2.064 & 1.806 & 1.533 & 1.563 & 46,200 \\
\hline
\end{tabular}




\begin{tabular}{|c|c|c|c|c|c|c|c|c|}
\hline 3 Digit NZSCO Occupation & $\begin{array}{c}\text { Total Annual } \\
\text { Net } \\
\text { Replacement } \\
1991-1996 \\
\end{array}$ & $\begin{array}{c}\text { Total Annual } \\
\text { Net } \\
\text { Replacement } \\
1996-2001\end{array}$ & $\begin{array}{c}\text { Total Annual } \\
\text { Net } \\
\text { Replacement } \\
2001-2006 \\
\end{array}$ & $\begin{array}{c}\text { Total } \\
\text { Employment } \\
1991\end{array}$ & $\begin{array}{c}\text { Total } \\
\text { Employment } \\
1996\end{array}$ & $\begin{array}{c}\text { Total } \\
\text { Employment } \\
2001\end{array}$ & $\begin{array}{c}\text { Total } \\
\text { Employment } \\
2006\end{array}$ & $\begin{array}{l}2006 \text { Mean } \\
\text { Income }\end{array}$ \\
\hline 414 Library, Mail and Related Clerks & $1.40 \%$ & $1.20 \%$ & $1.40 \%$ & 56,544 & 62,391 & 68,454 & 71,511 & 30,300 \\
\hline 611 Market Farmers and Crop Growers & $1.00 \%$ & $2.30 \%$ & $1.40 \%$ & 34,329 & 42,423 & 42,984 & 39,681 & 26,800 \\
\hline 121 General Managers & $1.20 \%$ & $1.40 \%$ & $1.30 \%$ & 39,234 & 50,508 & 43,077 & 50,955 & 66,700 \\
\hline 811 Mining and Mineral Processing Plant Operators & $1.60 \%$ & $0.90 \%$ & $1.30 \%$ & 1,317 & 1,458 & 1,563 & 2,085 & 50,200 \\
\hline 841 Building and Related Workers & $1.50 \%$ & $0.50 \%$ & $1.30 \%$ & 5,343 & 6,441 & 7,365 & 9,282 & 38,200 \\
\hline 235 Other Teaching Professionals & $0.90 \%$ & $1.10 \%$ & $1.30 \%$ & 900 & 1,188 & 1,464 & 2,565 & 48,700 \\
\hline 743 Tailors and Dressmakers & $1.40 \%$ & $1.30 \%$ & $1.20 \%$ & 6,231 & 6,585 & 5,550 & 5,961 & 33,800 \\
\hline 243 Archivists, Librarians and Related Information Professionals & $1.10 \%$ & $0.90 \%$ & $1.20 \%$ & 3,348 & 3,912 & 4,911 & 5,340 & 35,600 \\
\hline 234 Special Education Teaching Professionals & $0.80 \%$ & $1.00 \%$ & $1.20 \%$ & 1,860 & 3,186 & 4,248 & 4,494 & 33,700 \\
\hline 613 Forestry and Related Workers & $0.30 \%$ & $3.30 \%$ & $1.20 \%$ & 4,959 & 7.011 & 6,963 & 4,899 & 34,600 \\
\hline 713 Electricians & $1.90 \%$ & $1.60 \%$ & $1.10 \%$ & 12,099 & 11,784 & 12,081 & 14,217 & 43,600 \\
\hline 412 Numerical Clerks & $1.50 \%$ & $1.80 \%$ & $1.10 \%$ & 34,122 & 28,068 & 26,229 & 28,629 & 32,600 \\
\hline 222 Health Professionals (Except Nursing) & $2.40 \%$ & $0.90 \%$ & $1.10 \%$ & 12,252 & 12,621 & 15,024 & 18,045 & 85,000 \\
\hline 514 Other Personal Services Workers & $0.40 \%$ & $2.90 \%$ & $1.10 \%$ & 14,055 & 21,189 & 19,515 & 22,341 & 21,900 \\
\hline 821 Metal and Mineral Products Processing Machine Operators & $0.60 \%$ & $0.20 \%$ & $1.10 \%$ & 4,131 & 7.059 & 11,826 & 12,909 & 36,000 \\
\hline 914 Packers and Freight Handlers & $2.40 \%$ & $2.30 \%$ & $1.00 \%$ & 24,993 & 21,939 & 21,204 & 24,129 & 25,800 \\
\hline 614 Fishery Workers. Hunters and Trappers & $2.30 \%$ & $1.70 \%$ & $1.00 \%$ & 4,437 & 4.239 & 4.374 & 4.656 & 34,400 \\
\hline 413 Material Recording and Transport Clerks & $0.90 \%$ & $1.70 \%$ & $1.00 \%$ & 13,485 & 19,662 & 20,661 & 22,791 & 34,700 \\
\hline 3 Digit NZSCO Occupation & $\begin{array}{c}\text { Total Annual } \\
\text { Net } \\
\text { Replacement } \\
1991-1996 \\
\end{array}$ & $\begin{array}{c}\text { Total Annual } \\
\text { Net } \\
\text { Replacement } \\
\text { 1996-2001 }\end{array}$ & $\begin{array}{c}\text { Total Annual } \\
\text { Net } \\
\text { Replacement } \\
2001-2006 \\
\end{array}$ & $\begin{array}{c}\text { Total } \\
\text { Employment } \\
1991\end{array}$ & $\begin{array}{c}\text { Total } \\
\text { Employment } \\
1996\end{array}$ & $\begin{array}{c}\text { Total } \\
\text { Employment } \\
2001\end{array}$ & $\begin{array}{c}\text { Total } \\
\text { Employment } \\
2006\end{array}$ & $\begin{array}{l}2006 \text { Mean } \\
\text { Income }\end{array}$ \\
\hline 231 Tertiary Teaching Professionals & $2.80 \%$ & $1.30 \%$ & $1.00 \%$ & 12,006 & 12,573 & 13,944 & 16,335 & 54,000 \\
\hline 223 Nursing and Midwifery Professionals & $2.30 \%$ & $1.20 \%$ & $0.90 \%$ & 28,113 & 28,302 & 30,954 & 35,148 & 41,000 \\
\hline 825 Paper Products Machine Operators & $0.60 \%$ & $1.50 \%$ & $0.90 \%$ & 2,001 & 978 & 855 & 546 & 32,700 \\
\hline 334 Social Work Associate Professionals & $0.10 \%$ & $0.40 \%$ & $0.90 \%$ & 6,804 & 14,895 & 23,664 & 27,825 & 27,000 \\
\hline 336 Writers, Artists, Entertainment and Sports Associate Professionals & $0.80 \%$ & $0.80 \%$ & $0.90 \%$ & 17,946 & 23,481 & 28,980 & 37,788 & 34,200 \\
\hline 113 Senior Business Administrators & $0.90 \%$ & $0.40 \%$ & $0.90 \%$ & 459 & 816 & 9,840 & 14,493 & 81,300 \\
\hline 723 Machinery Mechanics and Fitters & $2.30 \%$ & $1.90 \%$ & $0.90 \%$ & 23,331 & 23,238 & 22,812 & 26,091 & 38,200 \\
\hline 513 Personal Care Workers & $0.70 \%$ & $0.30 \%$ & $0.90 \%$ & 17,889 & 26,238 & 36,249 & 39,396 & 19,500 \\
\hline 311 Physical Science and Engineering Technicians & $2.30 \%$ & $1.90 \%$ & $0.90 \%$ & 25,656 & 21,378 & 19,104 & 20,631 & 46,200 \\
\hline 112 Senior Government Administrators & $2.10 \%$ & $1.30 \%$ & $0.90 \%$ & 840 & 1,149 & 987 & 1,788 & 59,200 \\
\hline 242 Legal Professionals & $1.20 \%$ & $0.80 \%$ & $0.80 \%$ & 6,570 & 7,452 & 9,300 & 11,430 & 82,000 \\
\hline 241 Business Professionals & $1.40 \%$ & $0.50 \%$ & $0.80 \%$ & 24,780 & 27,912 & 42,489 & 53,820 & 61,100 \\
\hline 122 Specialised Managers & $1.90 \%$ & $1.30 \%$ & $0.80 \%$ & 120,609 & 134,703 & 160,350 & 213,288 & 54,400 \\
\hline 214 Architects, Engineers and Related Professionals & $0.90 \%$ & $1.80 \%$ & $0.80 \%$ & 16,956 & 22,173 & 21,552 & 27,402 & 59,600 \\
\hline 411 Secretaries and Keyboard Operating Clerks & $1.50 \%$ & $1.10 \%$ & $0.80 \%$ & 42,993 & 44,445 & 39,270 & 29,769 & 34,200 \\
\hline 733 Printing Trades Workers & $1.70 \%$ & $1.10 \%$ & $0.80 \%$ & 9,078 & 9,501 & 8,046 & 8,874 & 38,200 \\
\hline 511 Travel Attendants and Guides & $0.60 \%$ & $1.40 \%$ & $0.70 \%$ & 3,009 & 4,167 & 4,731 & 5,673 & 33,500 \\
\hline
\end{tabular}




\begin{tabular}{|c|c|c|c|c|c|c|c|c|}
\hline 3 Digit Frseo cccupation & $\begin{array}{l}\text { Total Annitial } \\
\text { Net } \\
\text { Replacemen } \\
\text { I 1981-1989 }\end{array}$ & $\begin{array}{l}\text { Total Annual } \\
\text { Not } \\
\text { Replacemen } \\
\text { t 1989-2001. }\end{array}$ & $\begin{array}{l}\text { Total Annual } \\
\text { Net } \\
\text { Replacenen } \\
\text { t2001-2006 }\end{array}$ & $\begin{array}{l}\text { Total } \\
\text { Employmen } \\
\text { t } 1991\end{array}$ & $\begin{array}{l}\text { Total } \\
\text { Employmen } \\
\text { t } 1988\end{array}$ & $\begin{array}{c}\text { Total } \\
\text { Enploym } \\
\text { ent } 2001\end{array}$ & $\begin{array}{l}\text { Total } \\
\text { Employmen } \\
\text { t2006 }\end{array}$ & $\begin{array}{l}2006 \\
\text { Mean } \\
\text { Income }\end{array}$ \\
\hline 315 Safety and Health Inspectors & $1.20 \%$ & $1.80 \%$ & $0.70 \%$ & 3,396 & 4,602 & 4,374 & 6,318 & 41,800 \\
\hline 314 Ship and Aircraft Controllers and Technicians & $1.20 \%$ & $2.10 \%$ & $0.70 \%$ & 3,081 & 3,744 & 3,717 & 4,500 & 72,300 \\
\hline 711 Building Frame and Related Trades Workers & $2.20 \%$ & $1.30 \%$ & $0.70 \%$ & 34,152 & 34,191 & 35,514 & 49,602 & 39,100 \\
\hline 832 Motor Vehicle Drivers & $1.40 \%$ & $0.70 \%$ & $0.70 \%$ & 30,813 & 32,805 & 35,061 & 39,366 & 35,300 \\
\hline 816 Power Generating and Related Plant Operators & $0.30 \%$ & $2.90 \%$ & $0.70 \%$ & 2,238 & 1,467 & 1,374 & 1,053 & 55,300 \\
\hline 244 Social and Related Science Professionals & $0.30 \%$ & $0.40 \%$ & $0.70 \%$ & 4,347 & 7,284 & 9,210 & 11,883 & 52,200 \\
\hline 114 Special-Interest Organisation Administrators & $0.90 \%$ & $2.60 \%$ & $0.60 \%$ & 822 & 1,242 & 1,416 & 1,917 & 40,000 \\
\hline 333 Government Associate Professionals & $1.70 \%$ & $0.40 \%$ & $0.60 \%$ & 1,101 & 1,017 & 1,359 & 1,971 & 45,400 \\
\hline 331 Finance and Sales Associate Professionals & $0.90 \%$ & $2.20 \%$ & $0.60 \%$ & 46,980 & 56,868 & 59,265 & 80,790 & 45,400 \\
\hline 814 Wood-Processing and Papermaking Plant Operators & $2.00 \%$ & $2.30 \%$ & $0.60 \%$ & 3,111 & 3,570 & 3,522 & 4,230 & 37,100 \\
\hline 323 Nursing Associate Professionals & $0.20 \%$ & $0.10 \%$ & $0.60 \%$ & 3,924 & 3,210 & 2,298 & 2,004 & 31,500 \\
\hline $\begin{array}{l}833 \text { Agricultural, Earthmoving and Other Materials-Handling Equipment } \\
\text { Operators }\end{array}$ & $0.90 \%$ & $0.80 \%$ & $0.60 \%$ & 9,432 & 12,057 & 13,446 & 16,527 & 37,600 \\
\hline 221 Life Science Professionals & $0.50 \%$ & $1.10 \%$ & $0.60 \%$ & 2,589 & 4,725 & 5,274 & 6,819 & 52,600 \\
\hline 812 Metal-Processing Plant Operators & $0.70 \%$ & $1.20 \%$ & $0.50 \%$ & 3,357 & 4,746 & 4,074 & 5.133 & 39,500 \\
\hline 915 Labourers & $2.80 \%$ & $1.90 \%$ & $0.50 \%$ & 38,118 & 39,468 & 29,232 & 46,431 & 26,800 \\
\hline 332 Administrative Associate Professionals & $0.60 \%$ & $1.00 \%$ & $0.50 \%$ & 13,713 & 20,031 & 15,300 & 22,323 & 42,000 \\
\hline 335 Careers and Employment Advisers & $2.30 \%$ & $0.60 \%$ & $0.40 \%$ & 1,035 & 1,056 & 957 & 1,320 & 44,200 \\
\hline 313 Optical and Electronic Equipment Controllers & $1.10 \%$ & $0.60 \%$ & $0.40 \%$ & 4,218 & 4,839 & 6.348 & 8,460 & 40,800 \\
\hline
\end{tabular}

\begin{tabular}{|c|c|c|c|c|c|c|c|c|}
\hline 3 Dieli Mrscoo Ocen ration & $\begin{array}{l}\text { Total Annual } \\
\text { Mot } \\
\text { Replacement } \\
\text { 1991-1998 }\end{array}$ & $\begin{array}{l}\text { Total Annual } \\
\text { Net } \\
\text { Replacement } \\
1996-2001 \\
\end{array}$ & $\begin{array}{l}\text { Total Annual } \\
\text { Met } \\
\text { Replacement } \\
2001-2006 \\
\end{array}$ & $\begin{array}{l}\text { Total } \\
\text { Employment } \\
1991 \\
\end{array}$ & $\begin{array}{l}\text { Total } \\
\text { Employment } \\
1996\end{array}$ & $\begin{array}{c}\text { Total } \\
\text { Employm } \\
\text { ent } 2001\end{array}$ & $\begin{array}{l}\text { Total } \\
\text { Employm } \\
\text { ent } 2006 \\
\end{array}$ & $\begin{array}{l}2006 \text { Mean } \\
\text { Income }\end{array}$ \\
\hline 315 Safety and Health Inspectors & $1.20 \%$ & $1.80 \%$ & $0.70 \%$ & 3.396 & 4,602 & 4.374 & 6,318 & 41,800 \\
\hline 314 Ship and Aircraft Controllers and Technicians & $1.20 \%$ & $2.10 \%$ & $0.70 \%$ & 3.081 & 3,744 & 3,717 & 4.500 & 72,300 \\
\hline 711 Building Frame and Related Trades Workers & $2.20 \%$ & $1.30 \%$ & $0.70 \%$ & 34,152 & 34,191 & 35,514 & 49,602 & 39.100 \\
\hline 832 Motor Vehicle Drivers & $1.40 \%$ & $0.70 \%$ & $0.70 \%$ & 30,813 & 32,805 & 35,061 & 39,366 & 35,300 \\
\hline 816 Power Generating and Related Plant Operators & $0.30 \%$ & $2.90 \%$ & $0.70 \%$ & 2,238 & 1.467 & 1,374 & 1,053 & 55,300 \\
\hline 244 Social and Related Science Professionals & $0.30 \%$ & $0.40 \%$ & $0.70 \%$ & 4,347 & 7,284 & 9,210 & 11,883 & 52,200 \\
\hline 114 Special-Interest Organisation Administrators & $0.90 \%$ & $2.60 \%$ & $0.60 \%$ & 822 & 1.242 & 1,416 & 1.917 & 40,000 \\
\hline 333 Government Associate Professionals & $1.70 \%$ & $0.40 \%$ & $0.60 \%$ & 1.101 & 1.017 & 1.359 & 1,971 & 45.400 \\
\hline 331 Finance and Sales Associate Professionals & $0.90 \%$ & $2.20 \%$ & $0.60 \%$ & 46,980 & 56,868 & 59,265 & 80,790 & 45,400 \\
\hline 814 Wood-Processing and Papermaking Plant Operators & $2.00 \%$ & $2.30 \%$ & $0.60 \%$ & 3,111 & 3.570 & 3.522 & 4,230 & 37,100 \\
\hline 323 Nursing Associate Professionals & $0.20 \%$ & $0.10 \%$ & $0.60 \%$ & 3,924 & 3,210 & 2,298 & 2,004 & 31,500 \\
\hline $\begin{array}{l}833 \text { Agricultural, Earthmoving and Other Materials-Handling Equipment } \\
\text { Operators }\end{array}$ & $0.90 \%$ & $0.80 \%$ & $0.60 \%$ & 9,432 & 12,057 & 13.446 & 16,527 & 37,600 \\
\hline 221 Life Science Professionals & $0.50 \%$ & $1.10 \%$ & $0.60 \%$ & 2,589 & 4,725 & 5,274 & 6,819 & 52,600 \\
\hline 812 Metal-Processing Plant Operators & $0.70 \%$ & $1.20 \%$ & $0.50 \%$ & 3,357 & 4,746 & 4,074 & 5.133 & 39,500 \\
\hline 915 Labourers & $2.80 \%$ & $1.90 \%$ & $0.50 \%$ & 38,118 & 39,468 & 29,232 & 46,431 & 26,800 \\
\hline 332 Administrative Associate Professionals & $0.60 \%$ & $1.00 \%$ & $0.50 \%$ & 13,713 & 20,031 & 15,300 & 22,323 & 42,000 \\
\hline 335 Careers and Employment Advisers & $2.30 \%$ & $0.60 \%$ & $0.40 \%$ & 1,035 & 1,056 & 957 & 1,320 & 44,200 \\
\hline 313 Optical and Electronic Equipment Controllers & $1.10 \%$ & $0.60 \%$ & $0.40 \%$ & 4.218 & 4,839 & 6.348 & 8,460 & 40,800 \\
\hline 212 Mathematicians, Statisticians and Related Professionals & $4.50 \%$ & $2.90 \%$ & $0.40 \%$ & 507 & 492 & 495 & 801 & 60,200 \\
\hline 321 Life Science Technicians and Related Workers & $2.00 \%$ & $2.00 \%$ & $0.30 \%$ & 5,040 & 4,719 & 4,494 & 5,664 & 35,100 \\
\hline 828 Leather and Related Products Processors & $0.90 \%$ & $1.50 \%$ & $0.30 \%$ & 1.038 & 1,338 & 1.101 & 666 & 32,000 \\
\hline 515 Protective Services Workers & $1.50 \%$ & $1.80 \%$ & $0.30 \%$ & 13,659 & 20,646 & 21,072 & 25.845 & 46,700 \\
\hline 213 Computing Professionals & $0.10 \%$ & $0.00 \%$ & $0.20 \%$ & 3,471 & 6.558 & 19.308 & 27,858 & 59.200 \\
\hline 338 Environmental Protection Associate Professionals & $0.00 \%$ & $0.00 \%$ & $0.20 \%$ & 921 & 99 & 330 & 522 & 36,200 \\
\hline Average across all 3 digit occupations & $1.60 \%$ & $1.60 \%$ & $1.40 \%$ & & & & & 538.900 \\
\hline
\end{tabular}

